\title{
CLASH OF TITANS: WILLIAM RANDOLPH HEARST AND HIS IMPACT ON AMERICAN FOREIGN POLICY DURING THE INTERWAR PERIOD
}

\author{
A Thesis \\ Presented to the Faculty of \\ California Polytechnic State University \\ San Luis Obispo \\ In Partial Fulfillment \\ Of the Requirements for the Degree \\ Master of Arts in History
}

By Brandon D. Roper

March 2010 
(C) 2008

Brandon D. Roper

ALL RIGHTS RESERVED 


\section{Committee Membership}

TITLE:

AUTHOR:

DATE SUBMITTED:

COMMITTEE CHAIR:

COMMITTEE MEMBER:

COMMITTEE MEMBER:
Clash of Titans: William Randolph Hearst and his impact on American Foreign Policy in the Interwar Period

Brandon D. Roper

March 24, 2010

Thomas Trice, Professor of History

Robert Detweiler, Professor of History

John Snetsinger, Professor of History 


\begin{abstract}
Clash of Titans: William Randolph Hearst and his impact on American Foreign Policy in the Interwar Period

The purpose of this thesis is to analyze a prominent figure of the $20^{\text {th }}$ century, William Randolph Hearst and to analyze the influence he was able to exert over American foreign policy through his own personal connections and those of his periodicals. This also includes an analysis between Hearst and Roosevelt, and noting the varying levels of influence between the two. This thesis will demonstrate that William Randolph Hearst is a prominent figure of $20^{\text {th }}$ century history, but was overshadowed by Roosevelt. Hearst while powerful was always putting his power into ventures that would backfire politically. When his papers declined, his influence over politics plummeted instantly.
\end{abstract}

Keywords: Hearst, American Foreign Policy, Isolationism, Interwar Period 


\section{TABLE OF CONTENTS}

Page

\section{CHAPTER}

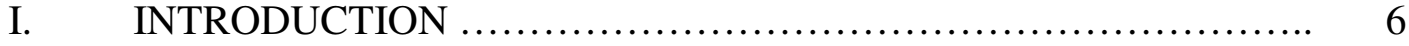

II. The Historiography of Hearst $\quad \ldots \ldots \ldots \ldots \ldots \ldots \ldots \ldots \ldots \ldots \ldots \ldots \ldots$

III. The Newspaper Market of the Interwar Period $\quad \ldots \ldots \ldots \ldots \ldots \ldots \ldots . . . . . .2$

IV. The Rise of Hearst: the 1920s $\quad$............................... 13

V. Hearst's Politics and Foreign Policy Agenda $\quad$................... 17

VI. American Issues and Hearst's Power $\quad$.......................... 26

VII. Hearst and Roosevelt over the World Court $\quad \ldots . . . . . . . . . . \ldots . . .29$

VIII. The Fall of Hearst: The Rise of Roosevelt $\quad \ldots \ldots \ldots \ldots \ldots \ldots \ldots \ldots \ldots \ldots . \quad 36$

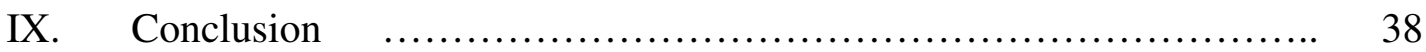

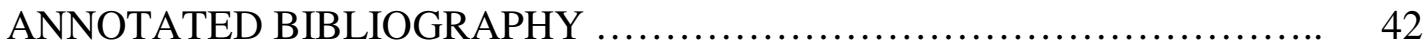




\section{$\underline{\text { Introduction }}$}

William Randolph Hearst, was well known throughout the world, and many both feared and envied his power to influence America's opinion on its foreign policy. $\mathrm{He}$ commanded a variety of media forms in his journalistic empire and exercised an iron fist over the editorial policy at all of his papers. The leaders of both the Axis and Allied Powers quailed under the power that Hearst's words had over America. Hearst is probably best known today through Orson Welles' famous quasi-biographical movie of Hearst "Citizen Kane" or for Hearst's role in the Spanish American War, in which the explosion of the U.S.S. Maine, was turned into a media spectacle, and galvanized public opinion for a war with Cuba. These events are well known, and accounted for in basic American history texts, and they explain Hearst's rise to power in the 1890s, and his impact on the foreign policy of that day ${ }^{1}$. However what is less well known is his influence later on, specifically during the inter-war period of the presidencies of Calvin Coolidge, Herbert Hoover and Franklin D. Roosevelt prior to Pearl Harbor, and how Hearst's manipulations reached what some would consider new highs and others new lows.

After the Great War ended and the Treaty of Versailles was implemented, Europe lay in ruins; but the masses of Europe held hope in Woodrow Wilson. Specifically they held hope in Wilson's League of Nations idea and a wish that wars would become relics of the previous age in humanity's history.

\footnotetext{
${ }^{1}$ Many high-school and Introductory American History Books cite the example of Hearst and how through the use of yellow journalism he started a war with Cuba. Ayers, Edward L. American Passages: A History of the United States. Vol. II. (Fort Worth: Harcourt Brace, 2000), 660.
} 
However, the League had its opponents in America. Hearst, in particular, despised the very concept of the League because he believed it went against American principles set by the Founding Fathers, and Hearst used his considerable resources to stop the United States from entering the international organization, or any sort of paninternational organization. The hope in the League of Nations was short lived as less than a generation later the second Great War, World War II would shatter all hope that people had in the League of Nations. The failure of the League of Nations had many causes but the one examined in this paper is America's conservative internationalism of the time, and Hearst's strenuous objections to having the United States join the League or any other international organization such as the emergent World Bank.

Hearst and his multi-national media conglomerate played a significant role in America's consistent rejection of internationalism, as Hearst maintained authoritarian editorial control over his papers. His strict editorial control resulted in numerous articles in Hearst papers that either reinforced Hearst's own views with very few exceptions². Despite Hearst's large influence, through the mass publication of his own editorials, radio addresses and the tremendous power his media empire had over the American public, his influence in America's foreign policy is largely overlooked. Hearst, however, exerted tremendous influence and had little tolerance for the games of Washington politicians, and he often blindsided politicians with scathing articles or unexpected endorsements. One of the most prominent examples was in 1932 when John Nance Garner, former Speaker of the House, was running against Franklin D. Roosevelt for the Democratic

\footnotetext{
2 Technically, editors of the various papers had the final say in whether or not to publish Hearst's editorials, but few took this opportunity.
} 
presidential nomination. Hearst supported Garner over Roosevelt for one simple reason: Garner wanted to stay out of the League and had a more conservative ideology regarding foreign policy. Hearst, who had recently switched parties following the failure of Hoover, used his influence in the hope that his own view of America's foreign policy would be followed by the next President, whoever that may be. In the end Hearst reached a compromise with Roosevelt so as to not deadlock the convention, and he had the power to instruct the Californian delegates to support Roosevelt at the Democratic National Convention. Hearst is an overlooked figure in the area of America's inter-war foreign policy; Hearst's influence, specifically through his newspapers, gave him considerable power that politicians both cursed and lusted after. Hearst used his papers to sway public opinion and frequently used his papers as a stage to present his views on America's role in the world. Hearst is an often ignored public figure, but despite being a private citizen and having no official power over either Congress or the President, he was able to manipulate both to suit his desire for an America that remained apart of foreign entanglements, as he believed the founding fathers wished for their new republic.

Hearst's notions were rapidly becoming outdated in a world ill-suited to match his ideology. Hearst was the last of $19^{\text {th }}$ century newspaper men like Greeley, but Hearst's influence was very much limited by his circulation numbers. He only wielded power when people listened to him or his papers. Once the Great Depression started, Hearst's Corporation fell into decline, and the policy agenda of Franklin D. Roosevelt doomed Hearst's media conglomerate to end its editorial directives, which Hearst used to enforce his influence on both domestic and foreign agendas, a setback that Hearst never recovered from in his lifetime. 


\section{The Historiography of Hearst}

There is a surprisingly sparse historiography on Hearst for a major figure of American History in the $20^{\text {th }}$ century. During Hearst's lifetime, few biographies were written about him that did not have a political agenda. One specifically attacked Hearst with historian Charles Beard penning the introduction ${ }^{3}$, and another was commissioned by Hearst as a response to said biography. Only a few articles in tangential subjects even mention Hearst, possibly out of a fear of reprisal from Hearst's papers. However in 1951, William Randolph Hearst passed away and shortly after his death a friend and business manager, Edmond Coblentz edited and published a book of Hearst's own writings, $\underline{A}$ Portrait of his own.

This collected work of Hearst's own writings dominated the field of Hearst study until the 1960s when W.A. Swanberg's Citizen Hearst was published. Swanberg wrote critically, focusing on the paradoxical nature of Hearst. For nearly half a century this volume stood as the standard, unchallenged biography of Hearst. ${ }^{4}$

In the 1990s and early 2000s the two most notable authors were David Nasaw who wrote the seminal biographical work The Chief, ${ }^{5}$ which argued against the common misconceptions regarding Hearst's personality and ideology and shook the structure of Hearst studies to its very core, upturning many of the preconceived notions historians had regarding Hearst.

\footnotetext{
${ }^{3}$ Ferdinand Lundberg. Imperial Hearst (New York: Equinox Cooperative Press, 1936).

${ }^{4}$ W.A. Swanberg. Citizen Hearst (New York: Charles Scribner's Sons, 1961), 357.

${ }^{5}$ David Nasaw. The Chief. (New York: Houghton Mifflin, 2000).
} 
In the 2000s David Proctor wrote a two volume biography, William Randolph Hearst, which focuses on the various contacts and machinations Hearst had in the foreign arena and the high society events at Hearst's home in San Simeon ${ }^{6}$. During this surge in the literature in recent years there have been specific efforts to focus on Hearst's foreign policy efforts. Ian Mugbridge's The View from Xanadu focuses on Hearst's views and impact on American foreign policy. Mugbridge notes Hearst's frequent changing of opinion on foreign policy ${ }^{7}$.

The Bancroft Library archives the papers of Hearst, his business manager and one time editor of the New York American, Edmond Coblentz, in addition to many of the rough drafts and final versions of Hearst's nationally distributed editorials. Other primary sources are the business memos, various correspondence and memorabilia regarding Hearst at the Bancroft Library The William Randolph Hearst Papers ${ }^{8}$, The John Francis $\underline{\text { Neylan Papers }}{ }^{9}$, and The Edmond Coblentz Papers ${ }^{10}$.

At the California State University's Library in San Luis Obispo there are several oral interviews available, with writers and staff for Hearst. Also a collection of cartoons

\footnotetext{
${ }^{6}$ Ben Proctor. William Randolph Hearst. Vol II (Oxford: Oxford University Press, 2007), 165, 204, 221222.

${ }^{7}$ Ian Mugbridge. The View from Xanadu. (Montreal: McGill-Queen's University Press, 1995), 4.

${ }^{8}$ William Randolph Hearst Papers, 1874-1951 (bulk 1927-1947). University of California - Bancroft Library, Berkeley, CA.

${ }^{9}$ John Francis Neylan Papers, papers circa 1911-1960. University of California - Bancroft Library, Berkeley, CA.

${ }^{10}$ Edmond Coblentz Papers, Papers, [ca. 1917-1960]. University of California - Bancroft Library, Berkeley, CA.
} 
regarding Hearst, which provided an entertaining context for how Hearst was seen by his opponents.

A trusted lieutenant of Hearst was Edmond Coblentz, a close friend entrusted with managing the New York American, one of the highest circulating newspapers in Hearst's conglomerate and the one that launched Hearst's publishing empire. Hearst was quite frank when talking with Coblentz, and their correspondence provides a clear picture into both men's minds. Coblentz, nicknamed "Cobbie”, also stuck with Hearst, eventually editing Hearst's dictations for an eventual autobiography into a book, shortly after the Newspaperman's death in the early 1950s.

John Francis Neylan, had a wide array of tasks and responsibilities from being editor of the San Francisco Call, to manager of Hearst's businesses, to political organizer of Hearst's chosen candidates. He provided cover for funds to be funneled into candidates' accounts, and he also was in a prime location in the Hearst hierarchy to determine how Hearst's directives affected the papers themselves.

Another of Hearst's lieutenants was his personal secretary, Joseph Willicombe, who managed Hearst's schedules and correspondence from San Simeon, and who typed or transcribed most of Hearst's correspondence. Other employees considered Willicombe to be vital to the corporation; when Willicombe left his job for retirement, Hearst never found an adequate replacement, ${ }^{11}$ contributing to business failures in the late 1930s. It was through Willicombe's due diligence that Hearst was able to micro-manage his widespread media conglomerate without modern technology, and as the business began

\footnotetext{
${ }^{11}$ Merryle Rukeyser, interviewed by Elizabeth deLancellotti, 1981.
} 
to falter, Willicombe retired. Unfortunately Willicombe never entrusted his papers to anyone, and I must consider then out of reach if they exist at all ${ }^{12}$.

\section{The Newspaper Market of the Interwar Period}

William Randolph Hearst had an enormous of amount of influence for only a private citizen because his assets included over 100 newspapers and journals. In the 1920s Hearst Newspapers commanded circulation numbers in the millions and was an innovator and mainstay in many markets in North America ${ }^{13}$, and during an interview Hearst once boasted that 1 in 4 Americans read a Hearst paper. He owned newspapers in San Francisco, Los Angeles, Seattle, New York City, even faraway London, and many more and in each of these major cities he commanded a majority or a significant market share $^{14}$. It is important to note that the newspaper market of the 1930 s was widely different than today's which has to compete with the radio, television news, 24 hour news channels and the internet. During the 1930s there were usually 3 major newspapers in each major city, and only rarely did one paper completely dominate a major city's market. In 1939, after the fall of Hearst's empire in the mid 1930s, New York City had seven major newspapers; Hearst's New York American was third in this market with a circulation of 600,000 . The New York Mirror had 740,000 in circulation and the New

\footnotetext{
${ }^{12}$ There was a reference I found that a Joseph Willicombe's papers were at a library in New York but I was unable to confirm, whether or not they were the papers of the correct Willicombe, and traveling to upstate New York was outside of my traveling range.

${ }^{13}$ David Nasaw. The Chief. (New York: Houghton Mifflin, 2000), xiv.

${ }^{14}$ Editor and Publisher. January 28, 1939. John Francis Neylan Papers. University of California - Bancroft Library, Berkeley, CA.
} 
York Daily Telegraph at $1,800,000^{15}$. A total market of over 2.5 million in a city that only had a population of Today The New York Times has a worldwide circulation of only $1,100,000$ in comparison. Quite simply the newspaper market was larger in the $1930 \mathrm{~s}$ than it is today due to the fact that both Radio and TV were yet to be fully realized as mediums for information. In comparison to the 1930s Media companies of New York City, the subscription numbers and share of readership for today's The New York Times would not even allow it to be considered a major newspaper in NewYork City.

\section{The Rise of Hearst: The 1920s}

From 1919 to 1932 , Hearst's conglomerate was at its peak, he had a commanding lead over his contemporaries, and led the fight in several national political debates. At this point Hearst's political power was at its peak. This was the era of conservative internationalism for America, when the United States wanted nothing to do with any international organization, and was rejecting all correspondence from the League of Nations, completely forsaking Wilson's dream.

Hearst who served in the House of Representatives from 1903 to 1907 with John Garner, was quite pleased with America's role in the world. Once quipping he knew that if the League of Nations vote came down to the House of Representatives, Hearst and Garner would lead the charge against it. Even decades later he believed that after his failed New York governor race or stint in the House of Representatives, Hearst still had a great deal of influences through his newspapers and political relationships.

\footnotetext{
${ }^{15}$ Editor and Publisher. January 28, 1939. John Francis Neylan Papers. University of California - Bancroft Library, Berkeley, CA.
} 
From San Francisco to New York, there was usually a Hearst paper in every major city in between. During an interview, a reporter asked him if he intended to acquire 100 papers, an amount unprecedented in the newspaper business, to which he replied that he had no more ambitions but if an opportunity presented itself he would acquire another $\operatorname{paper}^{16}$.

However Hearst's media influence was not just in the United States but overseas as well, and was one of the first multi-national media conglomerates. From as early as 1911, Hearst owned newspapers on the other side of the Atlantic, the London Budget, a relatively small paper in London, but one that Hearst believed had a chance at success. Although the paper never enjoyed wide scale success, or a large circulation, Hearst chalked it up to Europeans fear of "Yellow Peril", a particular fear of Hearst's brand of journalism which bordered on yellow journalism. This even prompted some banning of Hearst periodicals in both France and England ${ }^{17}$. Hearst was one of the many American businesses that was taking advantage of the post war period after the Great War in Europe. Even though the United States declined to join the League of Nations, for several years the United States was a major power, one which had an economy that dwarfed most of Europe's countries individually.

It should also be noted Hearst's conglomerate did not grow as quickly as it did because of Hearst's incredible management or surprising luck on the Stock Market. The corporation grew as quickly as it did thanks to Hearst's mother, Phoebe Hearst, giving Hearst the money to buy all these periodicals. After father George Hearst's death, Phoebe

\footnotetext{
${ }^{16}$ David Nasaw. The Chief. (New York: Houghton Mifflin, 2000), 322.

17 Ben Proctor. William Randolph Hearst: The Later Years. (Oxford: Oxford University Press, 2007), 50.
} 
controlled the family's checkbook, and although Hearst was wealthy and successful, Phoebe had access to far more money than William did. Phoebe gave out loans to Hearst which kept his business at a rate that was not driven by the market, but by Hearst's own $\operatorname{ambition}^{18}$.

In the end Hearst saw great success because of his acquisitions. Many of the magazines that he purchased (such as Better Homes and Gardens) are still profitable today and remain part of the Hearst Corporation. Although Hearst's ability to keep his profits and remain fiscally responsible was suspect, there can be no doubt that he knew how to create and operate profitable newspapers and magazines ${ }^{19}$.

Throughout the decade of the 1920s Hearst made many trips to Europe, and given his relationships with many European leaders, his trips merited quite the news story, especially since journalists were able to cover Hearst and the several movie stars that usually accompanied him. During this time period, Marion Davies always accompanied Hearst on his trips, and brought along many of her Hollywood friends, (On Hearst's fortune of course), which created a sensation wherever they visited.

During his trip in 1934, Hearst's trip through Europe was followed closely by journalist, almost causing a sensation wherever he went. This pattern of behavior was not uncommon, especially since in 1932 Hearst and his party were expelled from France, following an international incident caused by one of Hearst's papers publishing a French treaty that was at the time secret. Hearst's press conference shortly before his exile from

\footnotetext{
18 David Nasaw. The Chief. (New York: Houghton Mifflin, 2000), 104.

19 David Nasaw. The Chief. (New York: Houghton Mifflin, 2000), 102.
} 
France, was both pithy and filled with condemnation for the French government, and basically anything else about the country

Hearst reached his apex of influence over America's foreign policy in 1934, shortly after he reached the apex of his domestic political power in 1932. It was during this trip that Hearst toured Europe and made mention to a reporter of wanting to meet the German Chancellor. Although if Hearst's behavior is any indication, after he made this comment, he went out of his way to avoid meeting him, which made it all the more awkward when Adolf Hitler wished to meet him. Their meeting was very short, as Hearst cut it short, although he believed he was able to do some good with the meeting, he soon discovered that it was just a lie of Hitler, in the hopes of making an ally in America.

After completing his presidency in 1929, Calvin Coolidge visited California and accepted an invitation from Hearst to visit San Simeon. Hearst so admired the former president that he even sent down his own railway car to Los Angeles to pick up Coolidge, and ensured that no reporters would bother the former President, while he boarded the train in Los Angeles bound for San Simeon.

Known for his solitary personality, Coolidge found pleasure in the solitude of the San Simeon compound and also expressed his appreciation for the modern communications equipment that linked the retreat to the world beyond Hearst's isolated property. 


\section{Hearst's Politics and Foreign Policy Agenda}

Publisher Hearst held views on politics and international relations that he endlessly promoted with enthusiasm and passion through the papers and other forms of media he controlled through the 1920s and 1930s. To understand his influence, one must first understand the policies he so passionately promoted, in particular the rise of the political ideologies of communism and fascism.

A particularly direct statement of his beliefs appeared in the Hearst press in 1934, possibly in response to his meeting with Hitler. In an editorial that ran throughout his papers, titled "William Randolph Hearst on Fascism and Communism," Hearst asserted his opinion that communism was a philosophy of violence and terrorism and that the way 'communist' ideology was described in American schools failed to identify the reality of the communist threat to the United States and the world. The editorial described the disparity between the theoretical basis of communism as taught in American universities and the reality of Soviet communism. The reality was a nightmare of suppressing dissidents, ending any semblance of free expression, capricious executions, and brutal totalitarian regimes that denied basic freedoms. He also objected to communism on the grounds that the philosophy of Marx and Engels was in direct opposition to the philosophy of democracy and liberty that were laid down by the Founding Fathers of the United States, which Hearst valued more than any other political philosophy.

Hearst considered fascism to be only a secondary threat compared to the threat of communism, and believed that fascism was only the extreme response that was generated by communism. Furthermore, there would be no fascist states if there were no communist states. Hearst issued a memorandum to all editors regarding his campaign 
against communism, stating that throughout the papers all articles should reflect this view. If the backlash generated in academia is any indication across the entire country, then his editors did follow such a directive, despite the fact that they were not required to do $\mathrm{so}^{20}$.

Much of Hearst's editorial rhetoric was directed against what he saw as dangerous communist tendencies in academia in the United States. His goal was to draw attention to communism being taught in a positive light at some of America's colleges, claiming that many professors were merely theorists, and did not understand the actual practices of a communist government. Hearst insisted that the violent nature of communist regimes kept a country primitive and impoverished, constantly identifying the Soviet Union as the example.

The editorial spent little time discussing Fascism itself. Hearst considered the two similar enough, and were merely forms of foreign despotism, and that a distinction was not needed, but maintained that Fascism was compelled by Communism. Hearst remarked in his editorial that "Let us be alert to the dire menace of Communism which, as Lenin defines it, is "nothing else that power based upon force and limited by nothing by no kind of law, and by absolutely no rule.' And let us realize that there is no danger of Fascism as long as there is NO DANGER OF COMMUNISM.",21

In addressing the public the stance Hearst took was that of a patriotic American dedicated to guide national public opinion in the direction that would best serve the

\footnotetext{
20 Manual for Newspapers. William Randolph Hearst Papers, 1874-1951 (bulk 1927-1947). University of California - Bancroft Library, Berkeley, CA.

21 Communism and Fascism. Edmond Coblentz Papers, Papers, [ca. 1917-1960]. University of California Bancroft Library, Berkeley, CA.
} 
nation. In a 1939 national radio address, he specifically focused on the issue of what foreign policy agenda America should follow in perilous times. Sensing the importance of wanting to shape policy at a critical juncture in time, Hearst agonized over multiple drafts, word choices and the way in which content was delivered.

Mr. Hull's speech is very high sounding, and probably very well meaning. But what exactly DOES it mean?

If it means that America should be able to defend itself, and will defend itself, against any liberties by England or Germany or France or Italy or Japan, or any aggressive, militaristic nation whatsoever, then secretary Hull is right, and the people of America are behind him to a man.

But if Secretary Hull is merely parroting foreign propaganda, and if he means that America should takes sides in purely selfish conflicts between one form of imperialism and another - both equally repugnant to American ideals of liberty and democracy - then Secretary Hull's speech does not properly reflect the interest or intent of the American people...

...By all means let America arm invincibly for defense, but with proper provision that its armament be used ONLY for defense and for the preservation of American rights and liberties and institutions - NOT for the promotion of alien principles and the perpetuation of alien despotisms and imperialisms. ${ }^{22}$

An obvious plea for isolationism and an attack against what Hearst considered a new wave of internationalism under the Roosevelt administration. In this radio address he expressed concern over the British and French war debts to the US from World War I, Germany and Italy's Fascist regime and Communism in the Soviet Union, and the threat that all posed to American interests.

At the core of Hearst's belief was that that in foreign policy the essential guidelines outlined by the "Founding Fathers" in the eighteenth century remained the foundation of the country's relationship with the rest of the world. However his beliefs in

\footnotetext{
22 What is American Foreign Policy? Radio Address transcript from February 18, 1939. William Randolph Hearst Papers, 1874-1951 (bulk 1927-1947). University of California - Bancroft Library, Berkeley, CA.
} 
foreign policy were based on the what he perceived the founding fathers wanted, not on what Jefferson, Hamilton or Washington believed America's foreign policy should be.

One statement from George Washington, in fact the last address Washington gave the fledgling United States regarding alliances with Europe, “

It is our true policy to steer clear of permanent alliances with any portion of the foreign world; so far, I mean, as we are now at liberty to do it; for let me not be understood as capable of patronizing infidelity to existing engagements. I hold the maxim no less applicable to public than to private affairs, that honesty is always the best policy. I repeat it, therefore, let those engagements be observed in their genuine sense. But, in my opinion, it is unnecessary and would be unwise to extend them. ${ }^{23}$

This one paragraph formed the basis of Hearst's opinions of American Foreign

Policy. It ignored the actual policy of Washington, who made several treaties with Indian Nations; Jefferson who favored intervention in the French Revolution by American troops, or Hamilton and Franklin, who tried to negotiate a greater integration with Great Britain, to gain the protection of the British fleet on the High Seas. Hearst made no distinctions on the basis of parties, and held to the idea of "the Founding Fathers" rather then what the founding fathers actually accomplished. Hearst did as the founding fathers said in one circumstance, not what they did during their administrations of the young republic

This highlights a persistent problem of Hearst. Being an influential figure in the interwar period, Hearst was very aware of current affairs, but his awareness regarding the historical record was severely lacking, as evidenced by a comparison one of Hearst's

\footnotetext{
${ }^{23}$ Historic Documents "President George Washington's Farewell Address — 1796" ushistory.org http://www.ushistory.org/documents/farewelladdress.htm (accessed December 11, 2009)
} 
friends, Neylan sent him comparing Roosevelt and Oliver Cromwell ${ }^{24}$. This incident is notable because of the original comparison was sent to Neylan from the former minister of the Netherlands. Hearst was not a very deep thinker, more of a reactionary than a critical analyst of world affairs.

In reality Hearst did not critically analyze the motives, words or conduct of Washington beyond first president's initial words about "no entangling alliances." One of the quotes was Washington's line regarding “entangling alliances”, he did not read biographies of Jefferson or Hamilton, he did not consult historical experts regarding the founding fathers. In fact much of academia reviled Hearst and his conglomerate in the early 30s from Hearst's treatment of communism, and how Hearst distorted some facts about professors at Universities across the country regarding their communist tendencies and Anti-Americanism ${ }^{25}$.

Another example of Hearst's inability to base his foreign policy ideas on rational evidence is the way in which he viewed America's relationship with France. Hearst's attitude toward France was colored by one incident revolving around Hearst's papers disclosure of an Anglo-French treaty, which came to a head in 1930. During Hearst's stay in France the French police had him arrested and asked him and his entourage to leave the country. In the official communiqué which ordered the expulsion

The Presidency of the Council communicates the following: 'William Randolph Hearst, proprietor of numerous newspapers in America, was expelled

\footnotetext{
${ }^{24}$ Letter to J.F. Neylan from R.M. Tobin dated October 30, 1935. John Francis Neylan Papers, papers circa 1911-1960. University of California - Bancroft Library, Berkeley, CA.

${ }^{25}$ Carlisle, Rodney. The Political Ideas and Influences of William Randolph Hearst. (Berkeley: A UC Berkeley Doctoral Dissertation, 1963), Sec. XI.
} 
from French territory. This measure, taken upon the order of the President of the Council, Minister of the Interior, had as its origin the role played last year by $\mathrm{Mr}$. Hearst in obtaining and publishing a secret document relating to the Anglo-French naval negotiations. ${ }^{26}$

Interestingly, Hearst public reaction was radically different from his reaction in private.

In public he laughed off the incident, as humorous, saying that it was no great loss that he was expelled from the country but took the opportunity to insult France from his pulpit, lacing his response with sarcasm.

I have no complaint to make. The officials were extremely polite. They said I was an enemy of France and a danger in their midst. They made me feel quite important. They said I could stay in France a little while longer if I desired, that they would take a chance on nothing disastrous happening to the republic. But I told them that I did not want to take the responsibility of endangering the great French nation; that America had saved it once during the war, and I would save it again by leaving. ... It was a little foolish but extremely French. ${ }^{27}$

He closed his remarks with a scathing attack on France's treatment of Germany, and the many foreign debts that France pays the United States, because of the Versailles conditions gives France reparations from Germany. He presented the public image that it was a joke, but in private he was furious over this treatment. ${ }^{28} \mathrm{He}$ never travelled to France again, only flying over the country on any subsequent trip.

In fact his trip to Europe in 1934, the one that led to his meeting with Adolf Hitler, nearly danced entirely around France, going to Spain, Italy, Britain, Germany, and

\footnotetext{
${ }^{26}$ William Randolph Hearst and Edmond D. Coblentz ed. William Randolph Hearst: A Portrait in His Own Words. (Simon \& Schuster, 1952), 97.

27 William Randolph Hearst and Edmond D. Coblentz ed. William Randolph Hearst: A Portrait in His Own Words. (Simon \& Schuster, 1952), 97.

28 William Randolph Hearst and Edmond D. Coblentz ed. William Randolph Hearst: A Portrait in His Own Words. (Simon \& Schuster, 1952), 96.
} 
the Low Countries neatly avoiding France entirely. Hearst even banned the purchase of anything that France was exporting. In a note to his secretary, Hearst wrote: "Don't ever get me any more socks or anything else made in France." ${ }^{, 29}$ As a result of this slight dealt to him by the French Government, Hearst ordered his staff to buy nothing from any French company. This personal slight that was dealt to Hearst during his trip colored his entire opinion about the country and never returned. It was not the country's policy or agenda that bothered him but a personal slight that he had to leave the country for his newspaper's publishing of a government document. Hearst was unwilling to forgive the French even though France attempted to mend the bridge. Hearst would hear nothing of it ${ }^{30}$ holding France in disdain for the rest of his life.

The case of Great Britain was more complicated. Throughout the 1920s, Hearst and his family were friends with the family of Winston Churchill; the future prime minister even visited Hearst at San Simeon several times and contributed a few articles to Hearst papers on occasion ${ }^{31}$. On one trip to America Churchill was entertained by both of the women in Hearst's life, visiting both San Simeon and New York City. Hearst's first wife Millicent, whom he never divorced, was the hostess in New York while Marion Davies held forth in San Simeon. ${ }^{32}$

\footnotetext{
29 It should be noted that Hearst quadruple underlined France. William Randolph Hearst and Edmond D. Coblentz ed. William Randolph Hearst: A Portrait in His Own Words. (Simon \& Schuster, 1952), 102. 30 William Randolph Hearst and Edmond D. Coblentz ed. William Randolph Hearst: A Portrait in His Own Words. (Simon \& Schuster, 1952), 99.

${ }^{31}$ David Nasaw. The Chief. (New York: Houghton Mifflin, 2000), 417.

32 Ben Proctor. William Randolph Hearst: The Later Years. (Oxford: Oxford University Press, 2007), 152. During a trip to San Simeon a guide told a story about how Winston Churchill told his wife that he had met
} 
Hearst, as previously stated, owned newspapers in London as well as a castle, St. Donat's, which provided a niche economy of craftsman and artisans to furnish the castle during Hearst's ownership of that castle, similar to the effect San Simeon had during the construction of Hearst's mansion there. It is also of note that the San Simeon estate was never called Hearst Castle until after Hearst's death, and that St. Donats was the only true Hearst Castle.

During a commencement address that Hearst gave he spoke of his vision for peace in the world and proposed that the world needed to be protected by an Anglocoalition between the United States and Great Britain in 1927, is the most revealing of his attitude towards Great Britain. Despite his conservative foreign agenda Hearst did seem to want SOME means of keeping the world safe, just not the League of Nations or any other internationalist organization. Instead, Hearst sought an effectively an AngloAmerican security force that would guarantee the British Empire and the United States dominance over the world.

In my opinion, the universal establishment of peace must be attained through successive steps; and to my mind the first step is the establishment of an understandin between the English-speaking nations of the world...

I maintain however that it is not necessary or advisable for either the United States or the British Empire to occupy an inferior place, but that absolute equality, plus absolute sincerity, is the only practical basis on which such a compact can be effectively operated. ${ }^{33}$

It is clear from this quote that Hearst greatly admired the United Kingdom and enjoyed many privileges of this political position, and wished for greater cooperation

Marion Davies in San Simeon and Millicent Hearst in New York, and that "I have met Mrs. Hearst and they are both lovely."

${ }^{33}$ Oglethorpe Commencement Address. William Randolph Hearst Papers, 1874-1951 (bulk 1927-1947).

University of California - Bancroft Library, Berkeley, CA. 
between the United Kingdom and the United States to the point of an outright merging of the two countries into one globe spanning hegemony.

Hearst's opinion regarding the United States' southern neighbor, Mexico, was typical of many American's during the interwar period. In the 1920s Americans owned a good portion of the land of Mexico and the ownership of the Oil fields in Mexico, and Mexico itself was seen as an impoverished country. This played into the United States' policy of "Dollar Diplomacy," which made the disproportionate strength of the United States economy, financial and currency systems the methods by which the United States would dominate Latin America. In foreign policy this led the United States to uphold the Monroe Doctrine concept of excluding countries outside the western hemisphere from involvement in the affairs of Latin American countries. This effectively reduced many Central and South American countries to economic clients of the United States. Cuba's Platt Amendment, a bill passed by the Senate which effectively made Cuba's foreign policy the same as America's, and is the most jarring example of how the United States in the early $20^{\text {th }}$ century dictated policy to the Western Hemisphere, and declared economic dominion over most of Central and South America

Hearst owned both newspapers and property in Mexico. His property holdings were so large that Hearst called his property in San Simeon the "Little Ranch" and his property in Mexico, the "Big Ranch".

In 1927 Hearst newspapers purchased documents that supported the conclusion that Mexican president Calles had indeed supported the Sacasa rebellion in Nicaragua, over an issue of who had the presidency. After the rebellion Hearst papers published 
these documents, despite the impact it may have had on relations with America. Quickly authenticated, the papers published the offending documents. This created an international incident between the United States and Mexico ${ }^{34}$. It became the nationwide lead story in Hearst's papers for several weeks. The allegedly secret documents from the archives of Mexican President Calles which fingered Calles and Mexico directly involved with the Sacasa Rebellion, were discovered to be forgeries by the State Department and an international incident was avoided.

Secretary of the State Frank Kellogg, announced that the documents were fraudulent and that the international incident was unneeded. Hearst's enemies, both political and professional, immediately latched on to Hearst's failure, and were merciless in their attacks against the media magnate. The senate investigations eventually cleared Hearst of any wrongdoing, but Hearst's personal credibility and that of his newspapers were brought into question. From Hearst's perspective, this situation was a complete disaster. Hearst later remarked that " the loss of something over $\$ 20,000$ paid for the phony 'documents' was insignificant compared to his loss of credibility in publishing them"35.

\section{$\underline{\text { American Issues and Hearst's Power }}$}

In Domestic Policy, Hearst used his influence to force his own policies on the country. Using his own editorials he was able to advocate or tarnish the reputation of any politician. After the stock Market crash of 1929, and the ensuing depression, no political

\footnotetext{
34 "Mexico’s Aid to Sacasa.," New York Times, 14 November 1927, p. 2.

35 John F. Dunlap. The Hearst Saga: The Way it Really Was. (John F. Dunlap, 2002), 527.
} 
reputation was more tarnished than Herbert Hoover. Hoover's background as a businessman and philanthropist won him the applause of millions of American when he was elected president in 1928. Leaders in both parties at one time or another sought to nominate him for national office, but once the Great Depression began, the popularity of Hoover sank. He was quickly becoming the most hated man in America, a title that Hearst once held ${ }^{36}$. Hoover successfully won the Republican nomination to run again in 1932, but his chance of success appeared slim. The next President of the United States was surely thought to be a Democrat. However it was not clear which Democrat would be nominated. Would it be Roosevelt, McAdoo, Garner or Smith; Hearst himself had hated Hoover, and was ashamed that Hoover was a Californian let alone the President.

At the 1932 Democratic National Convention Hearst nearly made Roosevelt lose the convention. Texan Representative John Nance Garner, former Speaker of the House, was running against Franklin Delano Roosevelt for the Democratic presidential nomination. Hearst supported Garner (surprising Garner himself) over Roosevelt for one simple reason: Garner wanted the United States to stay out of the League, and knew Garner from Hearst's own stint in the House of Representatives ${ }^{37}$. Hearst used his influence in the hope that his own view of America's foreign policy would be followed by the next President.

Conventions for the party worked much differently before 1968, primaries were distractions of no importance, and the nomination always came down to the convention and some back room deals. The outcome was never predetermined like in modern

\footnotetext{
36 Ben Proctor. William Randolph Hearst. Vol II (Oxford: Oxford University Press, 2007), 30.

37 David Nasaw. The Chief. (New York: Houghton Mifflin, 2000), 187.
} 
elections, unlike modern Presidents, Roosevelt only had a hope of being the nominee when the convention started, like every other candidate. In the end Hearst reached a compromise with Roosevelt so as to not deadlock the nominating convention, and instructed the Californian delegates to support Roosevelt and to block Smith and others from victory, giving Roosevelt enough delegate votes to guarantee the nomination of the Democratic party.

Because of some back room deals: the intervention of Joseph Kennedy and a discussion with Garner and Roosevelt and Roosevelt's assurance to Hearst regarding the League of Nations that the California delegates to the Democratic Convention swung their votes away from Garner and towards Roosevelt, clinching the nomination for Roosevelt and eventually the Presidency ${ }^{38}$.

Roosevelt needed those delegates controlled by Hearst and Garner and for a brief moment Hearst with Garner held the fate of the $20^{\text {th }}$ century in their hands. The Roosevelt administration changed America over its tenure in office, engaging and winning the Second World War, federal relief programs from the Great Depression. For a day and a half Hearst held the fate of the world in his hand. It would be the apex of Hearst's political power, although Hearst did enjoy a degree of access with FDR in the early years of the presidency.

At the convention, after three ballots, Roosevelt was the clear leader, but he did not have the two-thirds majority necessary to clinch a victory for him under the 1932 convention rules. To avoid Al Smith and other candidates, pushing for a compromise

\footnotetext{
${ }^{38}$ Harold Ickes, The Secret Diary of Harold Ickes, (Simon and Schuster, 1953), 428.
} 
candidate and depriving Roosevelt of the nomination. Roosevelt needed the 100 votes that Hearst and Garner had for Garner's own Presidential bid. Hearst and Garner both agreed to support Roosevelt for assurances against joining the League of Nations. Roosevelt agreed, despite his own Wilsonian ideology with regards to foreign affairs.

After all the primary concern in American politics in 1932 was the Great Depression, not foreign affairs. As the 1930s progressed this would of course shift. Two months before Roosevelt's inauguration, Adolf Hitler became chancellor, and by the end of the 1930s would make foreign policy a national concern for America. In fact, Roosevelt ran for an unprecedented third term because of the tense international situation in 1940.

\section{Hearst and Roosevelt over the World Court}

In the 1930s, there was one proposal which was so diametrically opposed to Hearst's views in Foreign Policy, which he and Roosevelt clashed over. This issue was the United States becoming a member of World Court. No other topic in the area of foreign policy, besides the League of Nations, came close to being the antithesis of Hearst's ideals. The World Court represented the internationalist movement that Hearst thought was spawned by Wilson, pushed through the Senate by Roosevelt and would spell the end of America. Hearst was very selective about how America would present itself in foreign policy.

At a commencement address at Oglethorpe University in 1927 he hoped that the United States and the British Empire would forge a strong alliance, and that there would be no pan-international organization of any kind, just a world of defensive blocs, and 
economic zones ${ }^{39}$. Evidently despite the utter disaster of the Great War, Hearst continued believing in a continuation of the foreign policy of the Pre-war era. From his comments the only point of Wilson's Fourteen points that Hearst agreed with was the first and third: "Open covenants of peace, openly arrived at, after which there shall be no private international understandings of any kind but diplomacy shall proceed always frankly and in the public view"; and "The removal, so far as possible, of all economic barriers and the establishment of equality of trade conditions among all the nations consenting to the peace and associating themselves for its maintenance." ${ }^{40}$ Essentially Hearst wanted a continuation of the Dollar Diplomacy of the pre-Great War period, with an abandonment of secret diplomacy and alliances.

In 1935 America was showing positive signs of grown for the first time since 1929. For once Franklin Roosevelt could focus on foreign affairs not related to Great Depression and economic recovery. It was at this time that an internationalist movement started once more in the United States in regards to the Permanent Court of International Justice, more well known as the World Court, and the United States admission into it. Hearst and Roosevelt's relationship at this point was a tense one and this was going to be when Roosevelt and Hearst finally clashed in the realm of America's foreign policy.

Roosevelt had had one of the most productive first terms of any president because of his first hundred days and the New Deal and was almost assured re-election, he had a rare popularity among the American Presidents and was able to push through any sort of

\footnotetext{
39 Oglethorpe Commencement Address. William Randolph Hearst Papers, 1874-1951 (bulk 1927-1947). University of California - Bancroft Library, Berkeley, CA.

40 Dennis Merrill and Thomas G. Patterson. Major Problems in American Foreign Relations Volume II: Since 1914, (Houghton Mifflin Company, 2005), 39-40.
} 
agenda that he wished within reason. Hearst on the other hand was suffering, the vibrant newspaper magnate was suffering, his papers failing and conglomerate crumbling, and with declining sales so went a lot of Hearst's influence.

In 1935, Roosevelt attempted to have the United States join the World Court once again. This battle would bring together an unusual assortment of interests against the World Court. In the end Hearst newspapers, used every once of their political and economic pull with allies such as Huey Long, a staunch opponent of Roosevelt's direction of the Democratic party, and Father Coughlin to generate the popular support needed to defeat the ratification by the senate ${ }^{41}$.

This issue was not a new one for Hearst, he had standing orders to all of his newspapers and periodicals to push the issue of court admission to the fore of all possible political races, and of course smearing candidates that supported it. Hearst had these orders established as far back as 1929 when Hoover attempted to have the United States join the World Court. Back then Hearst Press was easily able to outmanuever Hoover, but now Hearst needed a coalition of allies to take down Roosevelt's plan for World Court admission. Therefore Hoover's inaugural promise to the American people failed because of Hearst.

In 1935 Hearst faced a much cleverer politician in Franklin Roosevelt, but met with a narrow defeat engineered by Hearst in January 1935. The issue of the United States in the World Court was voted down in a 52 to 35 decision on January 16, 1935. The vote has never come up again in the last 75 years. Hearst had finally had enough of

${ }^{41}$ David Nasaw. The Chief. (New York: Houghton Mifflin, 2000), 511. 
Roosevelt and ordered his newspapers to adopt a negative stance to the Presidency of Franklin Delano Roosevelt. This action didn't surprise Roosevelt in the least but still hoped to have Hearst's support in 1936 as long as he did not unduly annoy Hearst. Harold Ickes recorded in his journals that "The President remarked that, outside of Hearst and one or two other strings of newspapers, all the balance of the press of the country would be against him and naturally he wants all the support he can get. Therefore, he wants to watch his step on the Hearst matter..." ${ }^{42}$.

Hearst had hoped that through Roosevelt, he would have a voice through which he could shape national policy. He had already received Roosevelt pledge not to pursue United States entry into the League of Nations, or pursue an internationalist agenda and with Hearst swinging his delegates towards Roosevelt, he secured the nomination of the Democratic Party, resulting in Roosevelt getting a victory in a landslide against the incumbent Hoover. The Roosevelt Administration became one of the most important, if not the most important administration in American history. Throughout his tenure in office, FDR implemented federal relief programs, strengthened the military, and led America through its most trying hours, the worst economic depression and largest war in history, winning the war and recovering the nation. Hearst played an important role in getting FDR to the White House, one which he took too seriously and eventually wound up alienating Roosevelt from himself.

For a time after Roosevelt's Inauguration and the first hundred days both Hearst and Roosevelt got along well enough. Coblentz would frequently call the White House

42 David Nasaw. The Chief. (New York: Houghton Mifflin, 2000), 511. 
and get directed to "Frankie". ${ }^{33}$ At this time Hearst's opinion was that Roosevelt was a good man, sincere, sensible and a patriotic inspiration, who had idiotically chosen to "build his political band out of the discard of the Democratic party, and the refuse of the Hoover debacle". 44

During this time Hearst had the President called regarding the National Recovery Administration (NRA). Hearst hated that administration, and was an early point of heated contention between the two men, souring their relationship from the start. One such aspect of the NRA that Hearst wanted to stop at all costs was a plan to subsidize journalists in the same way that the Works Progress Administration helped ordinary Americans. Hearst instructed his aide to call the White House

Please tell the President that I consider his proposal to license the press under NRA is in direct violation of the Bill of Rights; that it is an abridgement of the freedom of the press guaranteed by the Constitution, and that I will fight his proposal with every means at my command, even if it means taking it to the Supreme Court of the United States and even if it costs me every nickel I possess. $^{45}$

As the aide started to read Hearst's message to one of the President's aides, Roosevelt, or Frank as he was called by the staff member came on the line and responded personally to Hearst's assistant "My proposal is a regulatory measure and in no sense will it abridge the freedom of the press. It is similar, in a sense, to the fire department rules. When you

\footnotetext{
43 William Randolph Hearst and Edmond D. Coblentz ed. William Randolph Hearst: A Portrait in His Own Words, (Simon \& Schuster, 1952), 160.

44 William Randolph Hearst and Edmond D. Coblentz ed. William Randolph Hearst: A Portrait in His Own Words, (Simon \& Schuster, 1952), 158.

45 William Randolph Hearst and Edmond D. Coblentz ed. William Randolph Hearst: A Portrait in His Own Words, (Simon \& Schuster, 1952), 161.
} 
violate the fire department regulations, the Chief steps in and compels you to conform, does he not?",46

The aide then responded "Yes, Mr. President, but he does not stop the presses"47. Once the NRA was declared unconstitutional, Hearst rejoiced and wrote an editorial on the importance of the freedom of the press is key to protection against a dictatorial form of government. Privately it was a warning shot from Hearst and worsened the relationship between the two men. Both sides seemed to have relented at this point, Hearst let the matter go, and Roosevelt did not pursue a recovery, subsidy, or nationalizing plan for journalists or reporters. As Roosevelt's New Deal plans began to be more and more extreme and in Hearst's view, anti-business, from this point on Hearst began to fall, as Roosevelt rose. Hearst's last hurrah so to speak would be in the defeat of the World Court in 1935.

In 1934 Hearst demonstrated a surprising deal of arrogance with regards to both his influence and political power. In that year President Roosevelt signed into law the Revenue act of 1934. This act significantly raised the tax rate for high-income citizens of the United States. In fact Edward Coblentz, Hearst's trusted lieutenant was invited to the White House to talk to the President about the tax plan, Hearst was not comforted by the President's words,

I want to save the capitalistic system; to save it is to give some heed to world thought of today... To combat... crackpot ideas, it may be necessary to

\footnotetext{
${ }^{46}$ William Randolph Hearst and Edmond D. Coblentz ed. William Randolph Hearst: A Portrait in His Own Words, 161.

47 William Randolph Hearst and Edmond D. Coblentz ed. William Randolph Hearst: A Portrait in His Own Words, 161.
} 
throw the forty-six men who are reported to have incomes in excess of $\$ 1,000,000$ a year to the wolves... Further it may be necessary to see to it vast estates bequeathed to one person are limited in size. ${ }^{48}$

Hearst's arrogance was that he believed that Roosevelt and his followers specifically were targeting him with these tax increases. Given the state of Hearst's conglomerate, profit margins were thin, but a tax rate increase threatened his holdings more than anything else. It was from this point on that Hearst began to attack Roosevelt in his newspapers, as best he could given Roosevelt's popularity, and his own patriotic stance. Regardless of Hearst's opinion, Roosevelt was still the president, and privately felt that Roosevelt could lead the nation down the path to a dictatorship, like Cromwell did for the British in the 17th century.

With the passage of time Roosevelt's patience with Hearst wore thin. Although appreciating the support Hearst provided both in the press and at the Democratic National Convention. President Roosevelt wearied of the endless string of requests issued by Hearst. In 1934 Hearst's anti-communist campaign cost him public support and depressed the sales of Hearst newspapers across the country. Rhetoric directed at the President constantly warned about the administration falling down the path of socialism or dictatorship, which in Hearst's mind was one in the same with communism. Roosevelt's foreign policy during this time was diverging from Hearst's isolationism. Whatever influences Hearst once had diminished with the passing years. Nowhere is this more evident than in fight over whether or not the United States should join the World Court, which was just after the apex of his political power. One which Hearst needed a coalition of political power to beat. In August 1935, Roosevelt had intercepted a Hearst

48 David Nasaw. The Chief. (New York: Houghton Mifflin, 2000), 512. 
internal memo, which called for all papers to call the New Deal, the Raw Deal instead. Roosevelt had finally had enough and struck back at the aging Hearst during a White House press briefing, Roosevelt was for the first time directly retaliating against Hearst, something that would have been a career ending move in the 20s was now easy to accomplish $^{49}$. Hearst and Roosevelt would never work together in any form, and soon after Hearst began to fall.

\section{The Fall of Hearst: The Rise of Roosevelt}

The rift grew ever wider between the two men, as Roosevelt's star rose, Hearst's continued to flounder, especially during his attempted manipulations of congress and Hearst's support for Landon in 1936. The Depression had ruined Hearst's conglomerate after that things were downhill for Hearst, which had by then already taken a mighty toll on the country, began to hurt Hearst's Newspapers.

Hearst's power began to diminish as he aged. When the Spanish American War started he was in his thirties, forty-six during the Treaty of Versailles. By the time FDR was in office he was seventy.

After Willicombe's departure, Hearst never found an able manager to replace $\operatorname{him}^{50}$. Combined with his age, and a lack of managerial skill at the top of the conglomerate, Hearst's once great media machine faltered. This combined with the Great Depression, ensured the end of an era in which Presidents, Dictators, and politicians had to be concerned about locking swords with the opinionated, complaining, backwards, and

\footnotetext{
49 David Nasaw. The Chief. (New York: Houghton Mifflin, 2000), 515

50 Merryle Rukeyser, interviewed by Elizabeth deLancellotti, 1981.
} 
arrogant and vindictive Hearst and his legion of reporters. Part of Roosevelt's plan to end the Depression involved the raising of taxes on the wealthy and corporations. Raising taxes on corporations hit Hearst and his conglomerate hard, as the corporation as a whole was over one hundred million in debt ${ }^{51}$. This was the state of Hearst's conglomerate in 1937 during the so called Roosevelt Recession. The state of the Hearst Corporation would not be reversed until the 1950s with the placement of new management and a restructuring. Hearst himself would not live to see it.

The modern Hearst Corporation bears little resemblance to Hearst's original conglomerate, focusing more on magazines and TV stations then newspapers. Hearst himself then died in 1951. He had changed the field of journalism with his conglomerate, covered multiple wars, and affected many domestic, and some foreign, policy debates. Without him influencing the delegates in 1932 we may have had someone besides Roosevelt as the president from 1932, to lead America through the Depression, even America's involvement in World War II would have been in question.

In 1947, Hearst now in his mid 80s had a heart condition, and his health continued to decline. Hearst moved from his luxurious San Simeon home to Beverly Hills to be closer to his cardiologist. Although his home in Los Angeles was miniscule in comparison to San Simeon, this home was still quite luxurious by anyone other than Hearst's standards ${ }^{52}$. Hearst slowly faded away, until August 14, 1951, when Hearst died at the age of 88 , after a career of over half a century, developing new forms of media for

\footnotetext{
${ }^{51}$ Nancy E. Loe. Hearst Castle: The Official Pictoral Guide. (Bishop, CA: Aramark, 1991), Back Cover Flap.

52 Hearst's Beverly Hills home was featured in the 1974 film "The Godfather" as the home of a film producer
} 
his news services: print, periodicals, photo journalism, movies and even TV, had forever defined the field of modern journalism.

\section{Conclusion}

The 19th and 20th centuries saw massive changes to way human society functions. The advent of quick communication, allowed the delivery of ideologies, advertisements, and messages of all types to be received in less than a few days time. The power of politicians to move masses was no longer just the people who were at the speech, but all those that would read it in a newspaper, or listen to it on a radio, or watch it on a television. Media conglomerates have a rare power in the 20th century, while politicians, generals and leaders of nations compete for airtime, it is the media conglomerate that can decide which message will be heard by millions and which ones will be relegated to ignominy.

William Randolph Hearst knew this, and used his corporation to the best of his ability to forge the world to his preference. With his strict editorial controls and high readership across the country, he could whisper in the ear of millions. He could decide elections, suade domestic and foreign policy, even decide who was President of the United States. He relished this power, and felt it his purpose to warn the populace of the dangers of the world, wherever they may be: communism, fascism, Germany, France, Hoover, Roosevelt, or marijuana. Hearst jealously guarded the power of his newspapers, leading politicians and others to both fear and lust for his support in their campaigns or initiatives. 
Hearst sought to use the power of mass media to forge a world of his choosing, and in his position as wielder of that power, thought himself invulnerable; able to calm dictators, to be the kingmaker and breaker of American politics. He did it easily in any California political race, he created an Anti-communism wave in America in the 1930s that would only rival McCarthy in its scope, and he chose who would go against Hoover in 1932, met with the most hated man in the world in 1934 to dissuade him from a dictatorship. However there were limits to the scope of Hearst's power, the grander his plans, the less power he wielded. Even with the power of a multi-national mass media corporation of both newspaper, radio and film reel, he did not have the fulcrum needed to move the world in his desired fashion. The backlash against Hearst because of the anticommunism wave he started, soured any influence he had over America's academia. His stranglehold on delegates at the Democratic National Convention in 1932, bought him some influence with President Roosevelt in the early years of the Great Depression. Adolf Hitler sought only to use Hearst to influence America, the country that Hearst did his best to see to a superior position. Regardless of his intentions and ideology Hearst did consider himself a patriot.

Hearst was the first to truly manage a multi-national media corporation, and was defining the role of media in an increasingly globalized world, but it was one he was unable to fully adapt to in his life. Eventually readership dropped due to people tiring of his moral crusades. Combined with the factors of the Great Depression, Hearst's blasé tendency to spend money, increasing antagonism among politicians and academia, and a declining leadership, led to Hearst's conglomerate being millions of dollars in debt. 
The Twentieth Century is one of the most pivotal centuries in human history, and Hearst is an overlooked contributor to that century. His influence over America's collective ear was able to shape America's role in the first third of the 20th century. From the Spanish American War to his tours of Europe in 1934, he symbolized America's conservative internationalist policy. But as the 20th century marched on, eventually new voices began to define America's role in the world. In many ways the rise Franklin Roosevelt, signaled the decline of W.R. Hearst. A patriot to his country that lies forgotten that was able to mold and shape both the domestic and foreign policies of the United States, a who was eventually surpassed, as the next generation began to take the reins of power.

However as Hearst aged his corporation began to fail as well. His conglomerate had a shrinking market share which was mostly ignored by Hearst. It's unlikely that anything could have been done to abate the failure of Hearst's conglomerate, as the corporation, even during its most successful age, borrowed money heavily from Hearst's parents and banks. Following a wide scale boycott organized by academics across the country hurt Hearst's newspapers across the country. With the declining market share, Hearst's influence went down across the country, Presidents, dictators and politicians no longer had to bend to Hearst's vindictive and unique political ideology. Hearst could not adapt to the generational shift of the next generation taking control of the world. Hearst was in his 70s when Roosevelt was inaugurated. By 1940 Hearst's influence was such that politicians could safely ignore him. Even his own personal papers are few after 1940. Hearst's papers quietly folded across the country, hardly remembered even by University archives beyond a few select locations, incredibly uncharacteristic considering the papers 
usually brash, gaudy, and occasionally inflammatory headlines. Hearst himself passed in much the same manner, dying in Los Angeles in 1951 at the age of 88.

As Hearst's corporation failed, the country that Hearst loved so much began to change into a form he did not feel was in its best interests. Franklin Delano Roosevelt, a charismatic president which had successfully led the country through a terrible economic depression, but also the largest war in history, brought the country Hearst so loved down a path that he disapproved, an internationalist one. Roosevelt was similar to Hearst but held nearly the opposite of Hearst's views. As stubborn as Hearst was he could not not stop America from changing to a more internationalist stance under Roosevelt. Hearst wished for a future where America and Britain would rule the world in a defensive bloc, but when the world was in peril during World War II, Roosevelt worked with many allies, not just Britain, to ensure the end of the Axis. The Allies that defeated the Axis, was the antithesis of Hearst's view on how foreign affairs should work. Hearst was stubborn and believed that if he used his influence to stop such changing developments it would not happen. He was mistaken, under Roosevelt, the times they were a'changin and not to Hearst's liking, and in the end his conglomerate failed because of his resistance to the changing of the United States to an internationalist stance. 


\section{Annotated Bibliography}

Ayers, Edward L. American Passages: A History of the United States. Vol. II. Fort Worth: Harcourt Brace, 2000.

Bailey, Thomas A. Woodrow Wilson and the Great Betrayal. New York: The MacMillan Company, 1945.

Beard, Charles. American Foreign Policy in the Making: 1932-1940. New Haven: Yale University Press, 1946.

Charles Beard is one of the most prominent American historians. His works defined American History for a generation. In this work Beard discusses the foreign policy of the United States just before World War II. Beard makes note of Hearst monumental importance to the foreign policy at the time, and his denouncement of such institutions as the World Court and the League of Nations. In addition to accounts regarding the various administrations foreign policy all the way back to Wilson.

On another note, while searching in the Hearst Papers I discovered several references to Beard changing his views on Hearst in the 1930s to Hearst's approval, however I have not been able to find any determine why Beard changed his mind.

Carlisle, Rodney. Hearst and the New Deal: the Progressive as Reactionary. New York: Garland Publishing, 1979.

His work on Hearst and the New Deal, which I loaned from the library primarily as a means of reference for his commentary on the dynamics between Roosevelt and Hearst, and the cause of their falling out in 1935. Carlisle benefitted from having direct access to the Bancroft library. However this work mostly deals with the New Deal, it is very important as a commentary about the at times tense relationship between Hearst and Roosevelt.

Carlisle, Rodney. "The Foreign Policy Views of an Isolationist Press Lord: W. R. Hearst and the." Journal of Contemporary History (Jul 1974): 217-227.

Carlisle, Rodney. The Political Ideas and Influences of William Randolph Hearst. Berkeley: A UC Berkeley Doctoral Dissertation, 1963.

This work by Carlisle was his dissertation for graduation from UC Berkeley. The work in particular discusses the political influence that Hearst wielded in American Politics. However in discussing his domestic influence, Carlisle had to bring up his views on foreign policy. Carlisle especially paid attention to his views on the Soviet Union, and 
how these were different than his views on American communism. In Carlisle's view Hearst was vilified by intellectuals and pro-communist students and became a symbol of fascism to that movement. Carlisle emphasizes that Hearst's own views were far from that.

Coolidge, Calvin. The Autobiography of Calvin Coolidge. New York, Cosmopolitan Book Corporation, 1931.

Cooper, John Milton Jr. Breaking the Heart of the World: Woodrow Wilson and the Fight for the League of Nations. Cambridge, UK: Cambridge University Press, 2001.

I checked this book out from the library for the Wilsonian perspective regarding foreign policy and Wilson's response to Hearst's attacks in the Press, in particular the Hearst press vehemence regarding America's entry into the League of Nations which was ultimately unsuccessful. However since I have relatively sparse information regarding Hearst opposition to the League during Wilson's administration I must drop this source.

\section{Dallek, Robert. Franklin D. Roosevelt and American Foreign Policy, 1932-1945. New York: Oxford University Press, 1979.}

Dallek is the pre-eminent historian dealing with Franklin Delano Roosevelt and his administration. Dallek asserts several times that Hearst was a constant thorn in Roosevelt's side especially in the mid 1930s when Roosevelt was attempting to get America in the World Court, and Hearst vehemently opposed such a move. The author clearly supports FDR's perspective on the events but is neutral regarding Hearst. This is surprising because attitudes towards Hearst in general encompass a wide spectrum with only a small middle ground.

\section{Davidson, Roger H., Susan Webb Hammond and Raymond W. Smock. Masters of the House: Congressional Leadership over Two Centuries. Boulder, CO: WestView Press, 1998.}

\section{Dickinson, Edwin D. "The Defamation of Foreign Governments." The American Journal of International Law (1928): 840-844.}

This work is a scathing attack on Hearst regarding his conduct in 1927 regarding Mexico. The incident was that Hearst forged documents showing evidence of communist infiltration in Mexico. Also the various American agencies response. The problem is that I have not found this incident documented anywhere else, and the Hearst Papers although they do go back as far as the 1910s, the bulk of the papers dealing with foreign policy are from the 1930s.

Diggins, John P. Mussolini and Fascism: The View from America. Princeton, NJ: Princeton University Press, 1972. 
This source has provided much detail on the relationship between Mussolini and America. This book is primarily used a reference along with Dunlap's work to prove that there was a connection between Mussolini and Hearst, since the Hearst Papers have no records of such a relationship. I suspect that those letters were simply discarded during World War II or before Hearst's papers became public access

\section{Dunlap, John F. The Hearst Saga: The Way it Really Was. John F. Dunlap, 2002.}

John F. Dunlap was the curator of a large collection of materials on Hearst (most of which were auctioned off a few years ago to buyers unknown), and in 2002 he privately published his own work regarding W.R.Hearst, following the sequence of events in his life, not focusing on specific themes but all of Hearst's life in chronological sequence. As he reproduces the documents usually, I must classify this as a compilation of primary sources, assembled in chronological sequence.

Grant, Howard H. and Robert H. Ferrell, eds. The Talkative President: The Off the Record Press Conferences of Calvin Coolidge. Amherst, MA: The University of Massachusetts Press, 1964.

Hearst, William Randolph and Edmond D. Coblentz ed. William Randolph Hearst: A Portrait in His Own Words. Simon \& Schuster, 1952.

This book was written by Hearst, and later edited by Hearst's assistant Coblentz after his death. However the book has a very odd history, as officially Hearst's name is not on the cover, but it is edited by Coblentz. However on the title page Hearst is not mentioned as the author only Coblentz as the editor is mentioned. In a way this book itself is very emblematic of the enigma that is William Randolph Hearst. In addition to the Hearst papers and Dunlap, this is one of my primary sources. This book also has Hearst's personal recollections regarding his meeting with Hitler.

Historic Documents “President George Washington's Farewell Address — 1796” ushistory.org http://www.ushistory.org/documents/farewelladdress.htm Accessed December 11, 2009.

Hoover, Herbert. The Memoirs of Herbert Hoover. New York: The MacMillan Company, 1952.

Ickes, Harold. The Secret Diary of Harold L. Ickes. New York: Simon and Schuster, 1953.

Kuehl, Warren F. and Lynne K. Dunn. Keeping the Covenant: American Internationalists and the League of Nations, 1920-1939. London: The Kent State University Press, 1997.

Loe, Nancy E. Hearst Castle: The Official Pictoral Guide. Bishop, CA: Aramark, 1991. 
Lundberg, Ferdinand. Imperial Hearst: A Social Biography. New York: Equinox Cooperative Press, 1936.

Merrill, Dennis and Thomas G. Patterson. Major Problems in American Foreign Relations Volume II: Since 1914. Boston: Houghton Mifflin Company, 2005.

McCoy, Donald R. Calvin Coolidge: The Quiet President. New York: The MacMillan Company, 1967.

Merrill, Dennis and Thomas G. Patterson. Major Problems in American Foreign Relations Volume II: Since 1914, Houghton Mifflin Company, 2005.

Mugbridge, Ian. The View from Xanadu. Montreal: McGill-Queen's University Press, 1995.

Mugbridge's work is currently the only historical work analyzing Hearst's influence in foreign policy. Many other sources touch on this topic but Mugbridge is the only source that makes it his focus. Mugbridge's work is well documented and a great source on the topic of my thesis. Ian Mugbridge's The View from Xanadu is completely devoted to Hearst and his impact on American foreign policy throughout his life evaluates Hearst's foreign policy influence over his lifetime and the causes of some of these attitudes especially his frequent changing of opinion on foreign policy. This is unfortunately the only work done by this author on Hearst, and he only undertook this project when his friend died leaving this work mostly in complete. Also unlike many of my sources he spends a considerable amount of time regarding the Pacific, which has relatively sparse information in contrast to Hearst and European Foreign Policy

Murray, Robert K. The Harding Era: Warren G. Harding and His Administration. Minneapolis: University of Minnesota Press,

Myers, William Starr. The Foreign Policies of Herbert Hoover 1929-1933. New York, Charles Scribner's and Sons, 1940.

Nasaw, David. The Chief. New York: Houghton Mifflin, 2000.

David Nasaw's book is one of the only four biographies of Hearst. It is well documented and very detailed and provides many quotes from Hearst both from his editorials and letters. This work is one of the most important books to my research as it has not only provided me with a wealth of information but a large bibliography in which to find other sources. This book has become one of my standard reference materials regarding Hearst.

Peterson, H. C. "British Influence on the American Press, 1914-17." The American Political Science Review (Vol. 31, No. 1. (Feb., 1937)): 79-88. 
This journal article discusses British Propaganda efforts in America during World War I. Most of the article does not discuss Hearst but there is a brief section where it was said that the British propagandists were constantly fighting against Hearst newspapers. It is included as I plan for it to be a citation where I will remark about foreign reaction to Hearst.

\section{Proctor, Ben. William Randolph Hearst. Oxford: Oxford University Press, 1998,} 2007.

This work is in fact two volumes dedicated to Hearst's life. The first volume covers Hearst's life from 1863 to 1910, and has little importance to my argument. It is only mentioned for the sake of completeness. The second volume covers Hearst's life from 1910 until his death in 1951. The primary importance of Proctor's biography is the greater emphasis placed on Hearst's social contact. The main thesis of Proctor's work is lacking however, and his central purpose solely seems to be to fill a void in the historiography regarding Hearst, although he is at times very positive towards Hearst.

\section{Roosevelt, Franklin D. F.D.R. His Personal Letters. New York: Duell, Sloan and Pearce, 1947}

\section{Rosen, Elliot. Hoover, Roosevelt, and Brains Trust. New York: Columbia University Press, 1977.}

\section{Swanberg, W. Citizen Hearst. New York: Charles Scribner's Sons, 1961.}

For many years Swanberg's book was not just a biography of Hearst, it was one of the only two quality biographies until recently the debut of Nasaw's the Chief and Proctor's own work. As a testament to Swanberg's longevity, his book is cited by the modern historical writers about Hearst, as Nasaw, Proctor, and Mugbridge, all cite Swanberg's book throughout. His thesis is that Hearst was an enigmatic and at times a paradoxical figure. Swanberg also adopts a mostly negative approach to Hearst, at times portraying him as a corporate imperialist and an inconsistent politician.

\section{Tebbel, John W. The Life and Good Times of William Randolph Hearst. New York: E.P. Dutton \& Co, 1952.}

Tebbel is the other past biography of Hearst that at one time dominated the field of Hearst historiography. Swanberg's work is much better, and Tebbel to be the inferior work of the two biographies. It is included solely for reference alongside Swanberg, as the two books are the ONLY representatives of Hearst's previous historiography.

\section{Timmons, Bascom N. Garner of Texas: A Personal History. New York: Harper \& Brothers Publishers, 1948.}

Timmons work is a seminal piece of history regarding, John Nance Garner, former speaker of the house, Democratic candidate for president, and one of Roosevelt's 
vice presidents during his presidency. Although this work is dated it has provided me with insights into the 1932 Democratic convention. I had hoped that from this work I would gain some insight into the various machinations of William Randolph Hearst at the convention, particularly concerning the California delegates. Unfortunately, or fortunately depending on your point of view, that the three sources that I consulted regarding the 1932 convention had virtually no agreement between their accounts. ProHearst authors discuss how Hearst made a deal with Roosevelt, Pro-Roosevelt authors discuss how Roosevelt triumphed in spite of Hearst, and Pro-Garner sources merely discuss the various mysteries and an ignorance or omission of what happened. As a result, I am convinced that I could look into the 1932 convention for months and still not arrive at a consensus on what happened between Hearst, Roosevelt and Garner. Also I learned that although Garner was intending to run for President he was surprised over the amount of support he received because of his views regarding foreign policy.

Walch, Timothy. At the President's Side: The Vice-Presidency in the Twentieth Century. London: University of Missouri Press, 1997.

Walworth, Arthur. Wilson and his Peacemakers: American Diplomacy at the Paris Peace Conference, 1919. New York: W.W. Norton and Company, 1986.

Wilbur, Ray L. and Arthur Mastick Hyde. The Hoover Policies. New York: Charles Scribner's Sons, 1937.

Wilson, Woodrow and compiled by Hampton Foley. Woodrow Wilson's Case for the League of Nations. Port Washington, New York: Kennikat Press, Inc. 1923.

\section{William Randolph Hearst Papers, 1874-1951 (bulk 1927-1947). University of California - Bancroft Library, Berkeley, CA.}

This is an incredible source of information. The entire collection covers 14 boxes, 46 cartons, 8 oversize folders, 9 oversize boxes. These contain a sheer wealth of information that I would be hard pressed to find anywhere else on the planet. William Randolph Hearst, decided to donate most of his papers to the Bancroft Library, and with few exception (notably any reference to Mussolini or Hitler interactions) no topic was censored. He kept a remarkable number of minutae, which in and of itself is important. Contained within was personal correspondence with Hearst's son who managed the New

York American, personal correspondence between Calvin Coolidge and Hearst regarding the various interwar elections, and correspondence with Franklin Roosevelt over Hearst's concerns about the New Deal and Foreign Policy. Also contained within were the relics of many political manipulations and editorial directives straight from Hearst himself. Hearst, wrote all of his editorials and forwarded his hand-written and commented copies to his editors for comments for final revision. Then he made notes in the margins when he was broadcasting the editorials. This means that I have Hearst's personal copy with notes he made concerning many topics in foreign policy. 
Also in the Hearst papers was evidence how he was able to get so much political control. It stems primarily from that newspapers were allowed to endorse candidates and things such as equal political advertising were not created as of yet. Since Hearst controlled around 15 newspapers in many of America's largest cities, he could make or break many politicians career at a word, regardless of local, state, or federal level. Since Hearst was very passionate about the foreign policy and foreign affairs of the United States, he used his influence to force politicians to re-evaluate their own views. These papers contained vast amounts of information regarding his goals for America, and the candidates he supported for President and why. It was this power that forced Roosevelt to change his views on the League of Nations in 1932. From these archives I can safely conclude that Hearst was one of the most powerful if not the most powerful private citizen, given the range of his power over America's leaders.

One particular item that greatly aids my argument is the "Manual for Newspapers" written by Hearst around the late 1920s and early 1930s (although the date on the cover is 1927, many sections have different years sited. The latest being 1932). This document was the Bible for Hearst editors and journalists around the country. The manual contained everything regarding the proper methodology of writing, how to handle politicians, and what issues Hearst papers will always support. Some particular items of interest include a full two page memo regarding Hearst's opinion regarding the World Court and the League of Nations.

Other interesting pieces are his editorials especially regarding fascism and Communism, and how wide of an audience he had for these pieces. He had editorials regarding a great deal of topics, including but not limited to: Fascism and Communism, Homeland for Dispossesed Jews, France, Foreign debtors. Some of which contain his personal notations on the side and multiple copies of past revisions. Also contained within is Hearst's commencement address at Oglthrope University, which caused quite a stir in its negativity towards England.

\section{John Francis Neylan Papers. University of California - Bancroft Library, Berkeley, CA.}

John Francis Neylan was the financial adviser for Hearst during the roaring $20 \mathrm{~s}$ and the Great Depression as well as managing the San Francisco Call, a prominent newspaper of the time in San Francisco. Neylan as Hearst's financial advisor was well aware of Hearst's political leanings as Neylan made checks to the campaigns several times, or spread word of Hearst's endorsement or damnation of a candidate.

Neylan was also in correspondence with politicians regarding personal visits to Hearst Castle or Wyntoon (Hearst's other estate). This includes at least a trip by Calvin Coolidge during his presidency, and a personal trip by Winston Churchill.

Neylan also analyzed the Hearst Empire, and many of his papers give an excellent perspective on how far flung Hearst's Media Empire was in the interwar period. 
Neylan was also one of the few people that Hearst trusted to read his editorials before publication, and although Neylan later left the Hearst organization he was always a valued friend to Hearst and one of his chief lieutenants

\section{Edmond Coblentz Papers. University of California - Bancroft Library, Berkeley, CA.}

Like Neylan, Coblentz was the editor in chief at one of Hearst's papers, specifically the New York American. He also kept several important essays about Communism and Fascism, and Hearst's views on the matter to Communism and Fascism. Of particular interest in this section is discussion of cartoons about the League of Nations along with quotes from Hearst regarding many foreign policy issues.

Most of the important details of Coblentz's papers are regarding small orders that Hearst sent him regarding editorial policy. These documents reinforce Hearst personal editorial control over his papers as nearly supreme.

\section{Merryle Rukeyser, interviewed by Elizabeth deLancellotti, 1981.}

This work found in the Special Collections at Cal Poly Library, is a an oral interview with Merryle Rukeyser, one of Hearst's Business and Financial editors. This interview is enlightening for several reasons. One it describes the relationship between several prominent players in Hearst's organization. Two it describes how Hearst himself went about his business. Three it describes the social life of Hearst castle and how Hearst used that as a tool for influence.

Rukeyser was also privy to some of the internal politics at play in Hearst's organization and how his failing health affected Hearst's judgement, along with brief information regarding Willicombe's retirement. 